UDC 519.853, 624.04

\title{
AN IMPROVED GRADIENT-BASED METHOD TO SOLVE PARAMETRIC OPTIMISATION PROBLEMS OF THE BAR STRUCTURES
}

\author{
I. D. Peleshko ${ }^{1}$, \\ Candidate of Technical Science, Associate Professor \\ V. V. Yurchenko², \\ Doctor of Technical Science, Associate Professor \\ ${ }^{1}$ Lviv Polytechnic National University \\ St. Bandery, 12, Lviv, 79013 \\ ${ }^{2}$ Kyiv National University of Construction and Architecture \\ Povitroflotskyj av., 31, Kyiv, 03680
}

DOI: $10.32347 / 2410-2547.2020 .104 .265-288$

\begin{abstract}
The paper considers parametric optimisation problems for the bar structures formulated as nonlinear programming tasks. The method of the objective function gradient projection onto the active constraints surface with simultaneous correction of the constraints violations has been used to solve the parametric optimisation problem. Equivalent Householder transformations of the resolving equations of the method have been proposed. They increase numerical efficiency of the algorithm developed based on the method under consideration. Additionally, proposed improvement for the gradient-based method also consists of equivalent Givens transformations of the resolving equations. They ensure acceleration of the iterative searching process in the specified cases described by the paper due to decreasing the amount of calculations. The comparison of the optimisation results of truss structures presented by the paper confirms the validity of the optimum solutions obtained using proposed improvement of the gradient-based method. The efficiency of the propoced improvement of the gradient-based method has been also confirmed taking into account the number of iterations and absolute value of the maximum violation in the constraints.

Keywords: parametric optimisation, non-linear programming task, gradient-based method, bar system, finite-element method
\end{abstract}

Introduction. Over the past 50 years, numerical optimisation and finite element method [7] have individually made significant advances and have together been developed to make possible the emergence of structural optimisation as a potential design tool. In recent years, great efforts have been also devoted to integrate optimisation procedures into the CAD facilities. With these new developments, lots of computer packages are now able to solve relatively complicated industrial design problems using different structural optimisation techniques.

Applied optimum design problems for the bar structures in some cases are formulated as parametric optimisation problems, namely as searching problems for unknown structural parameters, whose provide an extreme value of the specified purpose function in the feasible region defined by the specified constraints. In this case structural optimisation performs by variation of the structural parameters when the structural topology, cross-section types and node

(C) Peleshko I. D., Yurchenko V. V. 
type connections of the bars, the support conditions of the bar system, as well as loading patterns and load design values are prescribed and constants. Besides, mathematical model of the parametric optimisation problem of the structures includes the set of design variables, the objective function, as well as constraints, whose reflect in general case non-linear interdependences between them [10].

In cases if the purpose function and constraints of the mathematical model are continuously differentiable functions, as well as the search space is smooth, then the parametric optimization problems are successfully solved using gradient-based non-linear methods [11]. The gradient-based methods operate with the first derivatives or gradients only both of the objective function and constraints. The methods are based on the iterative construction such sequence of the approximations of the design variables that provides the convergence to the optimum solution (optimum values of the structural parameters) [17].

Additionally, a sensitivity analysis is a useful optional feature that could be used in scope of the numerical algorithms developed based on the gradients methods [8].

Although many papers are published on the parametric optimization of the structures, the development of a general computer program for the design and optimisation of building structures according to specified design codes remains an actual task. Therefore, in this paper, a gradient-based method is considered as investigated object. The main research question is the development of mathematical support and numerical algorithm to solve parametric optimisation problems of the building structures with orientation on software implementation in a computer-aided design system.

1. Parametric optimisation problem formulation. Let us consider a parametric optimisation problem of a structure consists of the bar members, which can be formulated as presented below: to find optimum values for geometrical parameters of the structure, bar's cross-section sizes and initial prestressing forces introduced into the redundant members of the bar system, whose provide the extreme value of the determined optimality criterion and satisfy all load-bearing capacities and stiffness requirements. We assume, that the structural topology, cross-section types and node type connections of the bars, the support conditions of the bar system, as well as loading patterns and load design values are prescribed and constants.

The formulated parametric optimisation problem can be stated as a nonlinear programming task in the following mathematical terms: to find unknown structural parameters $\vec{X}=\left\{X_{\imath}\right\}^{T}, \imath=\overline{1, N_{X}}$, providing the least value of the determined objective function:

$$
f^{*}=f\left(\vec{X}^{*}\right)=\min _{\vec{X} \in \Im_{1}} f(\vec{X}),
$$

in feasible region (search space) $\mathfrak{I}$ defined by the following system of constraints: 


$$
\begin{gathered}
\psi(\vec{X})=\left\{\psi_{\kappa}(\vec{X})=0 \mid \kappa=\overline{1, N_{E C}}\right\} ; \\
\varphi(\vec{X})=\left\{\varphi_{\eta}(\vec{X}) \leq 0 \mid \eta=\overline{N_{E C}+1, N_{I C}}\right\} ;
\end{gathered}
$$

where $\vec{X}$ is the vector of the design variables (unknown structural parameters); $f, \psi_{\kappa}, \varphi_{\eta}$ are the continuous functions of the the vector argument; $\vec{X}^{*}$ is the optimum solution or optimum point (the vector of optimum values of the structural parameters); $f^{*}$ is the optimum value of the optimum criterion (objective function); $N_{E C}$ is the number of constraints-equalities $\psi_{\kappa}(\vec{X})$, whose define hyperplanes of the feasible solutions; $N_{I C}$ is the number of constraints-inequalities $\varphi_{\eta}(\vec{X})$, whose define a feasible region in the design space $\mathfrak{I}$.

The vector of the design variables Eq. (1.1) can include as components unknown geometrical parameters of the structure, unknown cross-sectional sizes of the structural members, as well as unknown initial pre-stressing forces introduced into the specified redundant members of the structure.

The specific technical-and-economic index (material weight, material cost, construction cost etc.) or another determined indicator can be considered as the objective function Eq. (1.1) taking into account ability to formulate it analytical expression as a function of design variables $\vec{X}$.

Load-bearing capacities constraints (strength and stability inequalities) for all design sections of the structural members subjected to all design load combinations at the ultimate limit state as well as displacements constraints (stiffness inequalities) for the specified nodes of the bar system subjected to all design load combinations at the serviceability limit state should be included into the system of constraints Eqs. (1.2)-(1.3). Additional requirements, whose describe structural, technological and serviceability particularities of the building structure under consideration, as well as constraints on the building functional volume can be also included into the system Eqs. (1.2) - (1.3).

2. An improved gradient-based method to solve the parametric optimisation problem. The parametric optimisation problem stated as nonlinear programming task by Eqs. (1.1) - (1.4) can be solved using a gradientbased method. The method of objective function gradient projection onto the active constraints surface with simultaneous correction of the constraints violations ensures effective searching for solution of the non-linear programming tasks occurred when optimum designing of the building structures $[5,9]$.

The gradient-based method operates with the first derivatives or gradients only both of the objective function Eq. (1.1) and constraints Eqs. (1.2) - (1.3). The method is based on the iterative construction such sequence Eq. (2.1) of the approximations of the design variables Eq. (1.4) that provides the convergence to the optimum solution (optimum values of the structural parameters): 


$$
\vec{X}_{t+1}=\vec{X}_{t}+\Delta \vec{X}_{t},
$$

where $\vec{X}_{t}=\left\{X_{l}\right\}^{T}, \imath=\overline{1, N_{X}}$ is the current approximation to the optimum solution $\vec{X}^{*}$ that satisfies both constraints-equalities Eq. (1.2) and constraintsinequalities Eq. (1.3) with the extreme value of the objective function Eq. (1.1); $\Delta \vec{X}_{t}=\left\{\Delta X_{t}\right\}^{T}, \imath=\overline{1, N_{X}}$, is the increment vector for the current values of the design variables $\vec{X}_{t}$ (see Fig. 2.1); $t$ is the iteration's index. Start point of the iterative searching process $\vec{X}_{t=0}$ can be assigned as engineering's estimation of the admissible design of the structure.

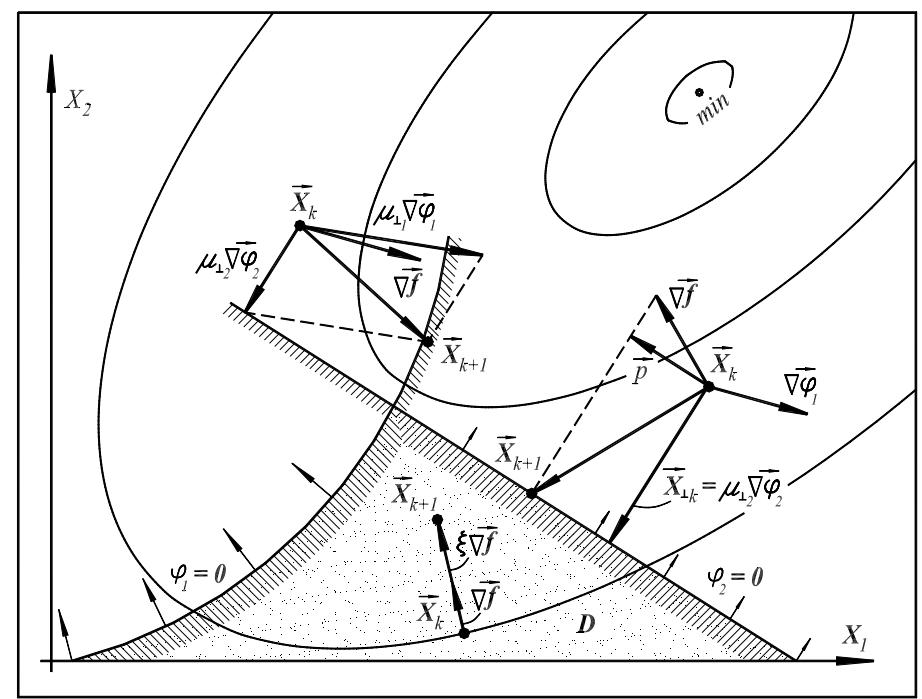

Fig. 2.1. Step to the optimum point depending on location of the current approximation in the N-dimension search space: graphical illustration

The active constraints only of constraints system Eqs. (1.2) - (1.3) should be considered at each iteration. Set of active constraints numbers A calculated for the current approximation $\vec{X}_{t}$ to the optimum solution (current design of the structure) is determined as:

$$
\mathbf{A}=\boldsymbol{\kappa} \cup \boldsymbol{\eta}, \boldsymbol{\kappa}=\left\{\kappa|| \psi_{\kappa}\left(\vec{X}_{t}\right) \mid \geq-\varepsilon\right\}, \boldsymbol{\eta}=\left\{N_{E C}+\eta \mid \varphi_{\eta}\left(\vec{X}_{t}\right) \geq-\varepsilon\right\} .
$$

where $\varepsilon$ is small positive number introduced here in order to diminish the oscillations on movement alongside of the active constraints surface.

Increment vector $\Delta \vec{X}_{t}$ for the current values of the design variables $\vec{X}_{t}$ can be determined by the following equation: 


$$
\Delta \vec{X}_{t}=\Delta \vec{X}_{\perp}^{t}+\Delta \vec{X}_{\|}^{t},
$$

where $\Delta \vec{X}_{\perp}^{t}$ is the vector calculated subject to the condition of liquidation the constraint's violations; $\Delta \vec{X}_{\|}^{t}$ is the vector determined taking into consideration the improvement of the objective function value. Vectors $\Delta \vec{X}_{\|}^{t}$ and $\Delta \vec{X}_{\perp}^{t}$ are directed parallel and perpendicularly accordingly to the subspace with the vectors basis of the linear-independent constraint's gradients, such that:

$$
\left(\Delta \vec{X}_{\perp}^{t}\right)^{T} \Delta \vec{X}_{\|}^{t}=0 .
$$

The values of the constraint's violations for the current approximation $\vec{X}_{t}$ of the design variables are accumulated into the following vector:

$$
\mathbf{V}=\left(\psi_{\kappa}(\vec{X}) \forall \kappa \in \boldsymbol{\kappa} ; \varphi_{\eta}(\vec{X}) \forall \eta \in \boldsymbol{\eta}\right) .
$$

Let introduce into further consideration set $\mathbf{L}, \mathbf{L} \subseteq \mathbf{A}$, of the constraint's numbers, such that the gradients of the constraints at the current approximation $\vec{X}_{t}$ to the optimum solution are linear-independent.

Component $\Delta \vec{X}_{\perp}^{t}$ is calculated from the equation presented below:

$$
\Delta \vec{X}_{\perp}^{t}=[\nabla \varphi] \vec{\mu}_{\perp} .
$$

where $[\nabla \varphi]$ is the matrix that consists of components $\frac{\partial \psi_{\kappa}}{\partial X_{t}}$ and $\frac{\partial \varphi_{\eta}}{\partial X_{t}}$, here $\imath=\overline{1, N_{X}}, \quad \kappa \in \mathbf{L}, \eta \in \mathbf{L} ; \vec{\mu}_{\perp}$ is the column-vector that defines the design variables increment subject to the condition of liquidation the constraint's violations. Vector $\vec{\mu}_{\perp}$ can be calculated as presented below.

In order to correct constraint's violations $\mathbf{V}$, vector $\Delta \vec{X}_{\perp}^{t}$ to a first approximation should also satisfy Taylor's theorem for the continuously differentiable multivariable function in the vicinity of point $\vec{X}_{t}$ for each constraint from set $\mathbf{L}$, namely:

$$
-\mathbf{V}=[\nabla \varphi]^{T} \Delta \vec{X}_{\perp}^{t} .
$$

With substitution of Eq. (2.4) into the Eq. (2.5) we obtain the system of equations to determine column-vector $\vec{\mu}_{\perp}$ :

$$
[\nabla \varphi]^{T}[\nabla \varphi] \vec{\mu}_{\perp}=-\mathbf{V} .
$$

Component $\Delta \vec{X}_{\|}^{t}$ is determined using the following equation:

$$
\Delta \vec{X}_{\|}^{t}=\xi \times \vec{p}_{\nabla f}=\xi\left(\nabla \vec{f}-[\nabla \varphi] \vec{\mu}_{\|}\right),
$$

where $\nabla \vec{f}$ is the vector of the objective function gradient in the current point 
(current approximation of the design variables) $\vec{X}_{t} ; \vec{p}_{\nabla f}$ is the projection of the objective function gradient vector onto the active constraints surface in the current point $\vec{X}_{t} ; \vec{\mu}_{\|}$is the column-vector that defines the design variable's increment subject to the improvement of the objective function value. Columnvector $\vec{\mu}_{\|}$can be calculated approximately using the least-square method by the following equation:

$$
[\nabla \varphi] \vec{\mu}_{\|} \approx \nabla \vec{f}
$$

or from the equation presented below:

$$
[\nabla \varphi]^{T}[\nabla \varphi] \vec{\mu}_{\|}=[\nabla \varphi]^{T} \nabla \vec{f}
$$

where $\xi$ is the step parameter, which can be calculated subject to the desired increment $\Delta f$ of the purpose function on movement along the direction of the purpose function anti-gradient. The increment $\Delta f$ can be assign as $5 \ldots 25 \%$ from the current value of the objective function $f\left(\vec{X}_{t}\right)$ :

$$
\Delta f=\xi(\nabla \vec{f})^{T} \nabla \vec{f}, \xi=\frac{\Delta f}{(\nabla \vec{f})^{T} \nabla \vec{f}},
$$

where in case of minimisation Eq. (1.1) $\Delta f$ and $\xi$ accordingly have negative values. The parameter $\xi$ can be also calculated using the dependency presented below:

$$
\xi=\frac{\Delta f}{\left(\vec{p}_{\nabla f}\right)^{T} \nabla \vec{f}},
$$

that follows from the condition of attainment the desired increment of the objective function $\Delta f$ on movement along the direction of the objective function anti-gradient projection onto the active constraints surface. Step parameter $\xi$ can be also selected as a result of numerical experiments performed for each type of the structure individually $[6,13]$.

Using Eqs. (2.4) and (2.7), Eq. (2.2) can be rewritten as presented below:

$$
\Delta \vec{X}_{t}=[\nabla \varphi] \vec{\mu}_{\perp}+\xi\left(\nabla \vec{f}-[\nabla \varphi] \vec{\mu}_{\|}\right),
$$

or

$$
\Delta \vec{X}_{t}=\xi \nabla \vec{f}+[\nabla \varphi]\left(\vec{\mu}_{\perp}-\xi \vec{\mu}_{\|}\right),
$$

where column-vectors $\vec{\mu}_{\perp}$ and $\vec{\mu}_{\|}$are calculated using Eq. (2.6) and Eq. (2.8) or Eq. (2.9).

The linear-independent constraints of the system Eqs. (1.2) - (1.3) should be detected when constructing the matrix of the active constraints gradients $[\nabla \varphi]$ used by Eq. (2.6) and Eq. (2.8) or Eq. (2.9). Selection of the linear-independent 
constraints can be performed based on the equivalent transformations of the resolving equations of the gradient-based method using the non-degenerate transformation matrix $\mathbf{H}$, such that the sub-diagonal elements of the matrix $\mathbf{H}[\nabla \varphi]$ equal to zero. Besides,

$$
\begin{gathered}
\mathbf{H}^{T} \mathbf{H}=\mathbf{I} ; \\
\mathbf{H}=\mathbf{H}_{t} \times \ldots \times \mathbf{H}_{i} \times \ldots \times \mathbf{H}_{2} \times \mathbf{H}_{1} ;
\end{gathered}
$$

where $\mathbf{I}$ is the unit matrix; $t$ is the total number of the linear-independent gradients of the active constraints, $\mathbf{H}_{i}$ is the transformation matrix, such that $\mathbf{H}_{i}^{T} \mathbf{H}_{i}=\mathbf{I}$, at the same time the sub-diagonal element are equal to zero in matrix $\mathbf{H}_{i} \times \mathbf{H}_{i-1} \times \ldots \times \mathbf{H}_{2} \times \mathbf{H}_{1} \times[\nabla \varphi]$ for column's numbers $\overline{1, i}$. Described conditions are satisfied by the orthogonal matrix of the elementary mapping (Householder's transformation) [18].

Let us present here the following algorithm to form set $\mathbf{L}$ and to construct matrix $\mathbf{H}[\nabla \varphi]$.

1. $i=0, \mathbf{L}=\varnothing$ and $[\nabla \boldsymbol{\Phi}]_{0}=[\nabla \varphi]$ should be assumed, where $[\nabla \varphi]$ is the matrix that comprises from the column-gradients of all active constraints. All columns of matrix $[\nabla \boldsymbol{\Phi}]_{0}$ should be marked as 'not used' (or linearindependent).

2. $i=i+1$.

3. Among all 'not used' columns of matrix $[\nabla \boldsymbol{\Phi}]_{i-1}$, whose correspond to the constraints-equalities Eq. (1.2), one $j^{\text {th }}$ column with extreme value of the specified criterion should be selected (for example, the following criterion $\ell_{j}^{2}=\sum_{k=i}^{N_{X}} g_{k j}^{2}$ can be considered as such criterion, where $g_{k j}$ are the $j^{\text {th }}$ column's components of matrix $[\nabla \boldsymbol{\Phi}]_{i-1}$ ). At the same time all $k^{\text {th }}$ columns of matrix $[\nabla \boldsymbol{\Phi}]_{i-1}$, for whose the following inequality $\ell_{k}^{2} \leq \varepsilon_{1}$ met, should be marked as 'used', here $\varepsilon_{1}$ is the small positive number. In case when no constraintsequalities exist or all constraints-equalities Eq. (1.2) are marked as 'used', the selection of $j^{\text {th }}$ column should be performed among all 'not used' columns of matrix $[\nabla \boldsymbol{\Phi}]_{i-1}$, whose correspond to the constraints-inequalities Eq. (1.3). If $\ell_{j}^{2} \leq \varepsilon_{1}$, then generation of set $\mathbf{L}$ and matrix $\mathbf{H}[\nabla \varphi]$ is finished. $\mathbf{H}[\nabla \varphi]=[\nabla \varphi]_{i-1}$. In case of $\ell_{j}^{2} \leq \varepsilon_{1}$ and $i=1$ (i. e. $\mathbf{L}=\varnothing$ ), there is a contradiction in the system of constraints Eq. (1.2)-(1.3). In other case, moving to the next step performs.

4. $k^{\text {th }}$ number of the constraint, that corresponds to the $j^{\text {th }}$ column number, 
should be included into set $\mathbf{L}, \mathbf{L} \leftarrow \mathbf{L}+\{k\}$.

5. Calculate $[\nabla \boldsymbol{\Phi}]_{i}=\mathbf{H}_{i}[\nabla \boldsymbol{\Phi}]_{i-1}$. It is reasonable to execute the multiplication only for 'not used' columns. It should be noted, when using Householder's transformation matrix $\mathbf{H}_{i}$ is not constructed evidently [18]. At the same time, matrix $[\nabla \boldsymbol{\Phi}]_{i}$ may be constructed within the ranges of matrix $[\nabla \boldsymbol{\Phi}]_{i-1}$ when no additional memory is needed.

6. If $i=1$, then $[\nabla \varphi]_{i}=\vec{q}_{j}$, where $\vec{q}_{j}$ is $j^{\text {th }}$ column-vector of matrix $[\nabla \boldsymbol{\Phi}]_{i}$. When $i>1[\nabla \varphi]_{i}$ is constructed using extension of the matrix $[\nabla \varphi]_{i-1}$ by the column-vector $\vec{q}_{j} . j^{\text {th }}$ column of matrix $[\nabla \boldsymbol{\Phi}]_{i}$ is selected as 'used', then moving to the step 2 performs.

Using Householder's transformations described above triangular structure of the nonzero elements of matrix $\mathbf{H}[\nabla \varphi]$ is formed step-by-step. Besides, Eq. (2.6) and Eq. (2.8) can be rewritten as follow:

$$
\begin{gathered}
\left([\nabla \varphi]^{T} \mathbf{H}^{T}\right)(\mathbf{H}[\nabla \varphi]) \vec{\mu}_{\perp}=-\mathbf{V} ; \\
\mathbf{H}[\nabla \varphi] \vec{\mu}_{\square} \approx \mathbf{H} \nabla \vec{f} .
\end{gathered}
$$

In order to calculate column-vectors $\vec{\mu}_{\perp}$ and $\vec{\mu}_{\|}$it takes only to perform forward and backward substitutions in Eq. (2.16) and Eq. (2.17).

To accelerate the convergence of the minimisation algorithm presented above, $h^{\text {th }}$ columns should be excluded from matrix $\mathbf{H}[\nabla \varphi]$. These columns correspond to those constraints from Eq. (1.3), for whose the following inequality satisfies:

$$
\mu_{\perp h}-\xi \times \mu_{\square h}>0 .
$$

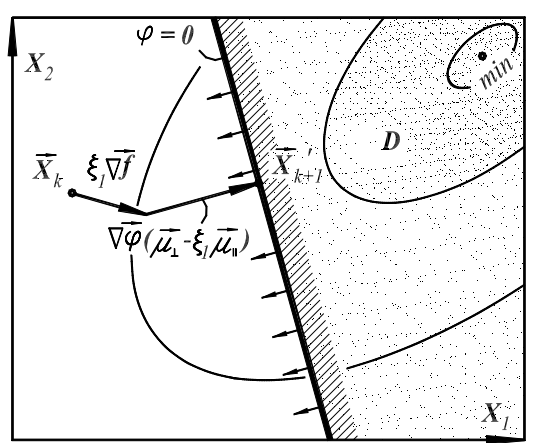

(a)

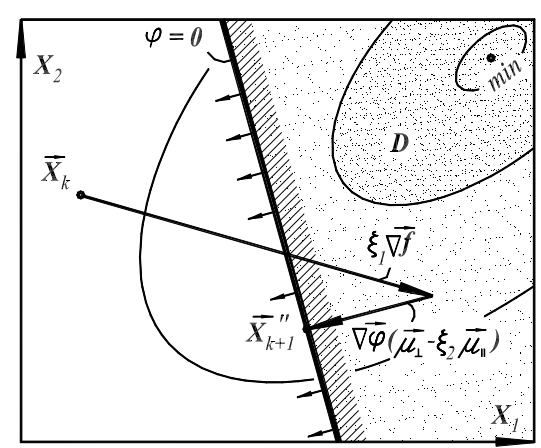

(b)

Fig. 2.2. Graphical illustration for the selection of the constraints-inequalities: graphical illustration: $a-\mu_{\perp h}-\xi_{1} \mu_{\llcorner h}<0 ; b-\mu_{\perp h}-\xi_{2} \mu_{\downarrow_{h}}>0$ 
Actually, when $\mu_{\perp h}-\xi_{2} \mu_{\neg h}>0$ return onto the active constraints surface from the feasible region $\mathfrak{I}$ with simultaneous degradation of the objective function value perform (see Fig. 2.2,b). At the same time, in case of:

$$
\mu_{\perp h}-\xi_{1} \mu_{\llcorner h}<0
$$

both improvement of the objective function value and return from the inadmissible region onto the active constraints surface perform (see Fig. 2.2, $a$ ).

When excluding $h^{\text {th }}$ columns from matrix $\mathbf{H}[\nabla \varphi]$ corresponded to those constraints for whose Eq. (2.12) satisfies, matrix $(\mathbf{H}[\nabla \varphi])_{\text {red }}$ with broken (nontriangular) structure of the non-zero elements is obtained. The set $\mathbf{L}$ of the linear-independent active constraints numbers transforms into the set $\mathbf{L}_{\text {red }}$ respectively. At the same time, the vector of the constraint's violations $\mathbf{V}$ reduced into the vector $\mathbf{V}_{\text {red }}$ accordingly.

In order to restore triangular structure of the matrix $(\mathbf{H}[\nabla \varphi])_{\text {red }}$ with zero sub-diagonal elements Givens transformations (Givens rotations) $[1,18]$ can be used. Givens transformations for the matrix $(\mathbf{H}[\nabla \varphi])_{\text {red }}$ consist of construction such square matrix $\mathbf{G}_{w z}$, for which corresponded $w z^{\text {th }}$ element of matrix $\mathbf{G}_{w z}(\mathbf{H}[\nabla \varphi])_{\text {red }}$ returns into zero (see Fig. 2.3) [12]. Since $c^{2}+s^{2}=1$ by definition, so it follows:

$$
\left(\mathbf{G}_{w z}\right)^{T} \mathbf{G}_{w z}=\mathbf{I} .
$$

Obvious method to calculate $c$ and $s$ for $d^{\text {th }}$ non-zero sub-diagonal element and for $a^{\text {th }}$ diagonal element is:

$$
c=\frac{a}{r}, s=\frac{d}{r}
$$

where

$$
r=\sqrt{a^{2}+d^{2}}
$$

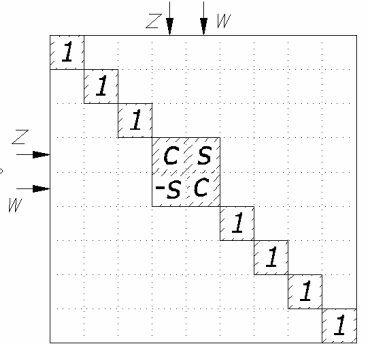

$\mathbf{G}_{w z}$

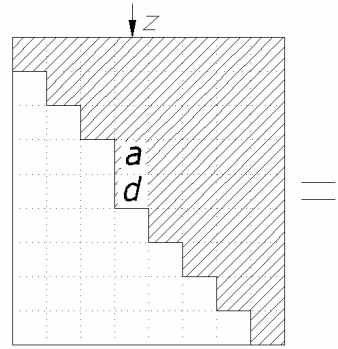

$(\mathbf{H}[\nabla \varphi])_{\text {red }}$

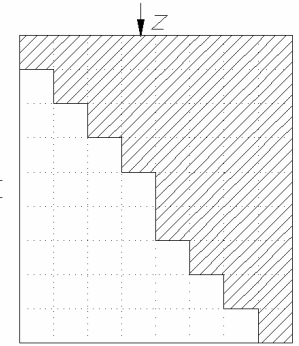

$\mathbf{G}_{w z}(\mathbf{H}[\nabla \varphi])_{\text {red }}$

Fig. 2.3. Scheme for Givens rotations (non-zero elements of the matrixes are dashed) 
The Givens matrix $\mathbf{G}$ may be calculated similarly to the matrix $\mathbf{H}$ using the following equation:

$$
\mathbf{G}=\mathbf{G}_{\gamma} \times \ldots \times \mathbf{G}_{i} \times \ldots \times \mathbf{G}_{2} \times \mathbf{G}_{1} .
$$

where $\gamma$ is the number of the Givens transformations. So, Givens transformations should be executed several times (with different values $z$ and $w)$, while the matrix $\mathbf{G}_{w z}(\mathbf{H}[\nabla \varphi])_{\text {red }}$ has no all zero sub-diagonal elements (for example presented by Fig. 2.3, $\gamma=5$ ).

Taking into account Givens transformations Eq. (2.16) and Eq. (2.17) to calculate column-vectors $\left(\vec{\mu}_{\perp}\right)_{\text {red }}$ and $\left(\vec{\mu}_{\square}\right)_{\text {red }}$ can be rewritten as:

$$
\begin{gathered}
\left([\nabla \varphi]^{T} \mathbf{H}^{T}\right)_{\text {red }} \mathbf{G}^{T} \mathbf{G}(\mathbf{H}[\nabla \varphi])_{\text {red }}\left(\vec{\mu}_{\perp}\right)_{\text {red }}=-\mathbf{V}_{\text {red }} ; \\
\mathbf{G}(\mathbf{H}[\nabla \varphi])_{\text {red }}\left(\vec{\mu}_{\square}\right)_{\text {red }} \approx \mathbf{G H} \nabla \vec{f} ;
\end{gathered}
$$

and the main resolving equation of the gradient-based method Eq. (2.12) and Eq. (2.13) can be rewritten as presented below:

$$
\Delta \vec{X}_{t}=(\mathbf{H}[\nabla \varphi])_{\text {red }}\left(\vec{\mu}_{\perp}\right)_{\text {red }}+\xi\left(\nabla \vec{f}-(\mathbf{H}[\nabla \varphi])_{\text {red }}\left(\vec{\mu}_{\|}\right)_{\text {red }}\right),
$$

or

$$
\Delta \vec{X}_{t}=\xi \nabla \vec{f}+(\mathbf{H}[\nabla \varphi])_{\text {red }}\left(\left(\vec{\mu}_{\perp}\right)_{\text {red }}-\xi\left(\vec{\mu}_{\|}\right)_{\text {red }}\right) .
$$

Proposed improvement for the method of the objective function gradient projection onto the active constraints surface with simultaneous correction of the constraints violations consists of equivalent transformations of the resolving equations using Householder transformations. The transformations with matrix H presented by Eq. (2.24) and Eq. (2.25) of the resolving equations of the gradient-based method Eq. (2.6) and Eq. (2.8) increase numerical efficiency of the algorithm developed based on the gradient-based method described above.

Additionally, proposed improvement for the gradient-based method includes equivalent transformations of the resolving equations using Givens rotations. The transformations with matrix $\mathbf{G}$ presented by Eq. (2.24) and Eq. (2.25) ensure acceleration of the iterative searching process Eq. (2.1) in case when Eq. (2.18) takes into account due to decreasing the amount of calculations.

It should be noted, that lengths of the gradient vectors for objective function Eq. (1.1) as well as for constraints Eqs. (1.2) - (1.3) remain as they were in scope of the proposed equivalent transformations ensuring the dependability of the optimisation algorithm.

Determination the convergence criterion is the final question when using the iterative searching for optimum point Eq. (2.1) described above. Taking into consideration the geometrical content of the gradient steepest descent method, we can assume that, at the permissible point $\vec{X}_{t}$ the component of the increment 
vector $\Delta \vec{X}_{\|}^{t}$ for the design variables should be vanish, $\Delta \vec{X}_{\|}^{t} \rightarrow 0$, in case of approximation to the optimum solution of the non-linear programming task presented by Eqs. (1.1) - (1.4). So, the following convergence criterion of the iterative procedure Eq. (2.1) can be assign:

$$
\left\|\Delta \vec{X}_{\|}^{t}\right\|=\sqrt{\sum_{l=1}^{N_{X}}\left(\Delta X_{\|, l}^{t}\right)^{2}}<\varepsilon_{1},
$$

where $\varepsilon_{1}$ is the small positive number.

Taking into consideration Eq. (2.28) let formulate the following stop criteria in the iterative searching procedure Eq. (2.1).

Stop criterion 1: in case of the objective function gradient in the current approximation $\vec{X}_{t}$ of the design variables is close to zero value indicating on extreme character of the current approximation, as well as violated constraints are absent:

$$
\left[\begin{array}{l}
\boldsymbol{\Sigma}=\varnothing \\
-\varepsilon \geq \nabla \vec{f} \geq+\varepsilon
\end{array}\right.
$$

where $\boldsymbol{\Sigma}$ is the set of the violated constraints numbers, $\boldsymbol{\Sigma}=\left\{s|| \psi_{s}\left(\vec{X}_{t}\right) \mid>\varepsilon ; \varphi_{s}\left(\vec{X}_{t}\right)>\varepsilon\right\}$;

Stop criterion 2: in case of the projection of the objective function gradient in the current approximation $\vec{X}_{t}$ onto the active constraints surface is close to zero value or objective function gradient is perpendicularly to the active constraints surface indicating impossible further improvement of the objective function value, as well as violated constraints are absent:

$$
\left[\begin{array}{l}
\boldsymbol{\Sigma}=\varnothing ; \\
-\varepsilon \geq \vec{p} \geq+\varepsilon ;
\end{array}\right.
$$

Stop criterion 3: when in the current approximation $\vec{X}_{t}$ of the iterative searching procedure (2.2) the total number of the active constraints $t$ equals to the number of design variables $N_{X}$, as well as all active constraints are $\varepsilon$ active (both not violated constraints and those ones for whose inequality Eq. (2.12) met):

$$
\left[\begin{array}{l}
\boldsymbol{\Sigma}=\varnothing ; \\
t=N_{X} ; \\
\mu_{\perp f}-\xi \times \mu_{\| f}<0, \forall f \in \mathbf{L} .
\end{array}\right.
$$

This stop criterion for the iteration process Eq. (2.1) corresponds to the case 
when the current approximation $\vec{X}_{t}=\left(X_{t}^{t}\right)^{T}, \imath=\overline{1, N_{X}}$, to the optimum solution locates at the intersection point of the constraints (so called, vertex). In this case, no correction of the constraints violations is needed and further improvement of the purpose function value is not possible.

Stop criterion 4: when the purpose function values within two consecutive iterations are the same with acceptable accuracy subject to the absence of the violated constraints:

$$
\left[\begin{array}{l}
\boldsymbol{\Sigma}=\varnothing ; \\
f\left(\vec{X}_{t-1}\right) \approx f\left(\vec{X}_{t}\right) .
\end{array}\right.
$$

3. Results and discussion. In order to estimate an efficiency of the new methods or algorithms, we should perform a comparison with alternative methods or algorithms presented by other authors using different optimisation techniques. Criteria to implement such comparison are described, i.e. by the papers $[2,6]$. Many of them, such as robustness, amount of functions calculations, requirements to the CPU memory, numbers of iterations etc. cannot be used due to lack of corresponded information in the technical literature. Therefore, an efficiency estimation of the method of objective function gradient projection onto the active constraints surface with simultaneous correction of the constraints violations presented above will be based on comparison of the optimisation results obtained using proposed improvement of the gradient-based method, as well as of the results presented by the literature and widely used for testing. Initial data and mathematical models of the parametric optimisation problems considered below were assumed as the same as described in the literature.

3.1. Parametric optimisation of a three-bar truss. Optimisation of a threebar truss (see Fig. 3.1) has been firstly solved by Schmit L. A. [15] using a nonlinear programming method. Besides, the task has been also considered by the authors of the paper [6].

A parametric optimisation problem was formulated as searching for optimum cross-sectional areas $b_{1}$, $b_{2}$ and $b_{3}$ of the truss bars providing the least value of the truss weight subject to normal stresses and flexural stability constraints, as well as displacements and eigenvalue constraints. Load cases for truss under consideration are presented by Table 3.1.

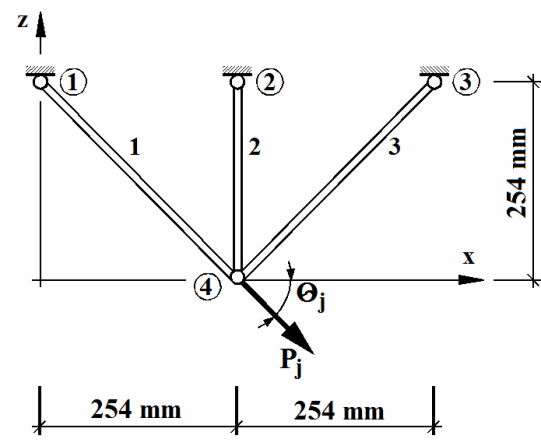

Fig. 3.1. Three-bar truss 
Table 3.1

Load cases for considered truss

\begin{tabular}{|c|c|c|c|}
\hline Load case $j$ & 1 & 2 & 3 \\
\hline$\theta_{j},{ }^{\circ}$ & 45 & 90 & 135 \\
\hline$P_{j} \times 10^{3}$, pound-force & 40 & 30 & 20 \\
\hline$P_{j}$, ton-force & 18.144 & 13.608 & 9.072 \\
\hline
\end{tabular}

Initial data for optimisation of the truss are as follows: unit weight of the truss material is $\rho g=0.1$ pound $/ \mathrm{inch}^{3}=2.768 \cdot 10^{-6} \mathrm{t} / \mathrm{cm}^{3}$; modulus of elasticity is $E=10^{7}$ pound $/$ inch $^{2}=703.066 \mathrm{t} / \mathrm{cm}^{2}$; allowable stresses value for the $1^{\text {st }}$ and $3^{\text {rd }}$ truss member is $\sigma_{1}^{a}=\sigma_{3}^{a}=5000$ pound $/$ inch $^{2}=0.3515 \mathrm{t} / \mathrm{cm}^{2}$; for the $2^{\text {nd }}$ truss member is $\sigma_{2}^{a}=2000$ pound $/ \mathrm{inch}^{2}=1.4061 \mathrm{t} / \mathrm{cm}^{2}$; non-dimensional factor used to calculate second moment area of inertia for each truss member is $\beta=1$, $I_{i}=\beta b_{i}$; ultimate vertical $z^{a}$ and horizontal $x^{a}$ displacements of the truss nodes are $x^{a}=z^{a}=0.005$ inch $=0.127 \mathrm{~mm}$; lower limit value for eigenvalue is $\zeta_{0}=1.872 \cdot 10^{8}$.

The objective function can be written as presented below:

$$
\psi_{0}=\rho g l\left(b_{1} \sqrt{2}+b_{2}+b_{3} \sqrt{2}\right) \rightarrow \min ;
$$

where $l$ is the truss height, $l=25.4 \mathrm{~cm}$ (see Fig. 3.1). Let formulate strength constraints for each truss members for all load cases as follows:

$$
\psi_{3(i-1)+j}=\frac{\left|N_{i}^{j}\right|}{b_{i} \sigma_{i}^{a}}-1 \leq 0 ;
$$

where $N_{i}^{j}$ is the axial force for $i^{\text {th }}$ truss member subjected to $j^{\text {th }}$ load case, $i=\overline{1,3}, j=\overline{1,3}$. Besides, let include to the system of constraints the inequalities describing that the design variables should have positive values:

$$
\psi_{9+i}=-b_{i} \leq 0
$$

Flexural buckling constraints for all truss members can be written using Hooke law as presented below:

$$
\psi_{12+3(i-1)+j}=-\frac{\left(x_{4}^{j}+z_{4}^{j}\right) l}{\pi^{2} \beta b_{i}}-1 \leq 0 ;
$$

where $x_{4}^{j}, z_{4}^{j}$ are linear displacements for $4^{\text {th }}$ node of the truss subjected to $j^{\text {th }}$ load case along the directions of $0 x$ and $0 z$ axes respectively. Constraints on the minimum values of the eigenvalues can be written analytically using calculation results of the eigenvalues stability problem for truss under consideration: 


$$
\psi_{22}=\frac{2 \sqrt{2} \rho l^{2} \zeta_{0}\left(\frac{b_{1}+b_{3}}{b_{2}} \sqrt{2}+1\right)}{3 E\left(\frac{b_{1}+b_{3}}{b_{2}}+\sqrt{2}-\sqrt{\left(\frac{b_{1}-b_{3}}{b_{2}}\right)^{2}+2}\right)}-1 \leq 0 .
$$

Let also formulate displacements constraints for $4^{\text {th }}$ truss node in the plane $x 0 z$ :

$$
\begin{aligned}
& \psi_{22+j}=-1-\frac{x_{4}^{j}}{x^{a}} \leq 0 ; \\
& \psi_{25+j}=\frac{x_{4}^{j}}{x^{a}}-1 \leq 0 ; \\
& \psi_{28+j}=-1-\frac{z_{4}^{j}}{z^{a}} \leq 0 ; \\
& \psi_{31+j}=\frac{z_{4}^{j}}{z^{a}}-1 \leq 0 .
\end{aligned}
$$

Starting from start values of the design variables $\vec{b}^{0}=(64.5160,32.2580,32.258)^{T} \mathrm{~cm}^{2}$ with truss weight $G^{0}=116.602 \mathrm{~N}$ optimum solution $\vec{b}^{*}=(57.4878,12.4482,27.4299)^{T} \mathrm{~cm}^{2} \quad$ with optimum weight $G^{*}=91.383 \mathrm{~N}$ has been obtained. Comparison of the optimisation results for three-bar truss under consideration obtained by authors of the paper [6] and in this article is presented by Table 3.2. Step-by-step characteristics of the iterative searching for optimum design of the three-bar truss are presented by Table 3.3.

Table 3.2

Comparison of the optimisation results for three-bar truss

\begin{tabular}{|c|c|c|c|}
\hline \multirow{2}{*}{$\begin{array}{c}\text { Truss member } \\
\text { number, } i\end{array}$} & \multirow{2}{*}{$\begin{array}{c}\text { Start values of the } \\
\text { design variables }\end{array}$} & $\begin{array}{c}\text { Optimum cross-section areas for } i^{\text {th }} \text { truss } \\
\text { member, } \mathrm{cm}^{2}\end{array}$ \\
\cline { 3 - 4 } & & Paper [6] & This paper \\
\hline 1 & 64.5160 & 59.225688 & 57.487781 \\
\hline 2 & 32.2580 & 13.935456 & 12.448249 \\
\hline 3 & 32.2580 & 24.838660 & 27.429940 \\
\hline Truss weight, $\mathbf{N}$ & $\mathbf{1 1 6 . 6 0 2}$ & $\mathbf{9 1 . 5 8 8 4 3 8}$ & $\mathbf{9 1 . 3 8 2 6 8 9}$ \\
\hline
\end{tabular}

11 iterations have been performed. Iterative searching process for the optimum point was stopped due to the following stop criterion: increment of the design variables within two consecutive iterations was less than 0.0001 , as well as there were no violated constraints. 
Table 3.3

Step-by-step characteristics of the iterative searching for optimum design of the three-bar truss

\begin{tabular}{|c|c|c|c|c|c|c|}
\hline \multirow{2}{*}{ 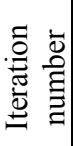 } & \multicolumn{3}{|c|}{$\begin{array}{l}\text { Current values of the design } \\
\text { variables, } \mathrm{cm}^{2}\end{array}$} & \multirow{2}{*}{$\begin{array}{c}\text { Objective } \\
\text { function value, } \\
\text { ton-force }\end{array}$} & \multirow{2}{*}{$\begin{array}{l}\text { Numbers of } \\
\text { the active } \\
\text { constraints }\end{array}$} & \multirow{2}{*}{$\begin{array}{l}\text { Maximum } \\
\text { violation of the } \\
\text { constraints }\end{array}$} \\
\hline & $b_{1}$ & $b_{2}$ & $b_{3}$ & & & \\
\hline 0 & 64.5160 & 32.2580 & 32.2580 & 130 & - & - \\
\hline 1 & 44.5160 & 22.2580 & 22.2580 & 0.00820412802 & 15 & 0.358346583 \\
\hline 2 & 60.78468 & 12.2580 & 12.2580 & 0.008124 & $\begin{array}{c}10,15,18,22 \\
24,33,34\end{array}$ & 0.462764185 \\
\hline 3 & 40.78469 & 14.85774 & 22.2580 & 0.00731284150 & $15,18,22,26$ & 0.422373593 \\
\hline 4 & 55.57631 & 15.86132 & 21.5254 & 0.00878127279 & 15,22 & 0.100763871 \\
\hline 5 & 57.39339 & 13.01145 & 26.33674 & 0.00923995830 & 15,22 & 0.011887395 \\
\hline 6 & 57.58708 & 12.55355 & 27.23679 & 0.00931651373 & 15,22 & 0.000269880 \\
\hline 7 & 57.49673 & 12.45692 & 27.41397 & 0.00931835396 & 15,22 & $9.66743 \cdot 10^{-6}$ \\
\hline 8 & 57.48847 & 12.44889 & 27.42879 & 0.00931844122 & 15,22 & $7.55468 \cdot 10^{-8}$ \\
\hline 9 & 57.48783 & 12.44830 & 27.42985 & 0.00931844180 & 15,22 & $1.42876 \cdot 10^{-9}$ \\
\hline 10 & 57.48778 & 12.44825 & 27.42993 & 0.00931844180 & 15,22 & $8.73750 \cdot 10^{-11}$ \\
\hline 11 & 57.48778 & 12.44825 & 27.42994 & 0.00931844180 & 15,22 & $6.55025 \cdot 10^{-12}$ \\
\hline
\end{tabular}

3.2. Optimisation of a ten-bar cantilever truss. A parametric optimization problem of a ten-bar cantilever truss (see Fig. 3.2) is widely used in the literature $[3,6,14,16]$ in order to compare different methods for solving optimisation problems. The parametric optimisation problem is formulated as follows: to find unknown cross-sectional areas for each truss member $\vec{b}=\left(b_{i}\right)^{T}, i=\overline{1,10}$, with weight minimisation of the truss subjected to stresses constraints in all truss bars, node displacements constraints, as well as constraints on the minimal cross-section areas.

The truss under consideration is undergone for two load cases (see Fig. 3.2 together with Table 3.4). Initial data for optimisation of the truss are as follows: unit weight of the truss material is $\rho g=0.1$ pound $/$ inch $^{3}=2.768 \cdot 10^{-6} \mathrm{t} / \mathrm{cm}^{3}$; modulus of elasticity is $E=10^{7}$ pound $/$ inch $^{2}=703.066 \mathrm{t} / \mathrm{cm}^{2}$; non-dimensional factor used to calculate second moment area of inertia for each truss member is $\beta=1.0\left(I_{i}=\beta b_{i}^{2}\right)$; lower limit value for cross-sectional areas for all truss bars is $b^{L}=0.10 \mathrm{inch}^{2}=0.64516 \mathrm{~cm}^{2}$; allowable stresses value for the all truss member is $\sigma^{a}=25 \cdot 10^{3}$ pound $/$ inch $^{2}=1.758 \mathrm{t} / \mathrm{cm}^{2}$; ultimate vertical $z^{a}$ and horizontal $x^{a}$ displacements of the truss nodes are $x^{a}=z^{a}=2$ inch $=50.8 \mathrm{~mm}$. Start value $b_{0}=1.0 \mathrm{inch}^{2}=6.4516 \mathrm{~cm}^{2}$ was used as start approximation for variable cross-sections areas for all bars of the truss under consideration. 


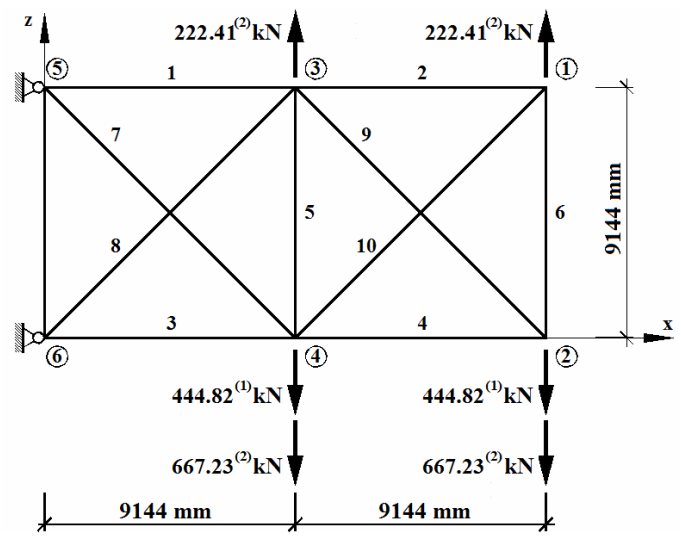

Fig. 3.2. Ten-bar cantilever truss

Table 3.4

Load cases for ten-bar cantilever truss

\begin{tabular}{|c|c|c|c|}
\hline $\begin{array}{c}\text { Load case } \\
\text { number }\end{array}$ & $\begin{array}{c}\text { Node } \\
\text { number } \\
\text { see Fig. 3.2) }\end{array}$ & $\begin{array}{c}\text { Concentrated load } \\
\text { along axis 0z, } \\
\times 10^{3} \text { pound }\end{array}$ & $\begin{array}{c}\text { Concentrated load } \\
\text { along axis 0z, }\end{array}$ \\
\hline \multirow{2}{*}{1} & 2 & -100.0 & -45.35901659 \\
\cline { 2 - 4 } & 4 & -100.0 & -45.35901659 \\
\hline \multirow{3}{*}{2} & 1 & 50.0 & 22.67950830 \\
\cline { 2 - 4 } & 2 & -150.0 & -68.03852489 \\
\cline { 2 - 4 } & 3 & 50.0 & 22.67950830 \\
\cline { 2 - 4 } & 4 & -150.0 & -68.03852489 \\
\hline
\end{tabular}

Variable cross-section areas for each truss member $\vec{b}=\left(b_{i}\right)^{T}, i=\overline{1,10}$, were considered as design variables. The objective function can be written as presented below:

$$
\psi_{0}=\rho g l\left(b_{1}+b_{2}+b_{3}+b_{4}+b_{5}+b_{6}+\sqrt{2}\left(b_{7}+b_{8}+b_{9}+b_{10}\right)\right) \rightarrow \min ;
$$

where $l$ is the truss height, $l=914.4 \mathrm{~cm}$ (see Fig. 3.2). Constraints on lower limit value for variable cross-sectional areas for all truss bars are written as follows:

$$
\psi_{i}=1-\frac{b_{i}}{b_{i}^{L}} \leq 0 .
$$

Stresses constraints can be formulated as presented below:

$$
\psi_{10+i}=\frac{\left|N_{i}\right|}{b_{i} \sigma_{i}^{a}}-1 \leq 0 .
$$

where $N_{i}$ is the axial force in the $i^{\text {th }}$ truss member. Displacement constraints 
for the truss nodes are written as follows:

$$
\begin{aligned}
& \psi_{20+j}=-1-x_{j} / x^{a} \leq 0 ; \\
& \psi_{24+j}=x_{j} / x^{a}-1 \leq 0 ; \\
& \psi_{28+j}=-1-z_{j} / z^{a} \leq 0 ; \\
& \psi_{32+j}=z_{j} / z^{a}-1 \leq 0 ;
\end{aligned}
$$

\begin{tabular}{|c|c|c|c|c|c|}
\hline \multirow{3}{*}{$\begin{array}{c}\text { Bur } \\
\text { number, } i\end{array}$} & \multirow{3}{*}{$\begin{array}{l}\text { Start values } \\
\text { for design } \\
\text { variables }\end{array}$} & \multicolumn{4}{|c|}{ Optimal cross-section area for $i^{\text {th }}$ truss member, $\mathrm{cm}^{2}$} \\
\hline & & \multicolumn{2}{|c|}{ for the first load case } & \multicolumn{2}{|c|}{ for the second load case } \\
\hline & & Paper [6] & This paper & Paper [6] & This paper \\
\hline 1 & 6.4516 & 193.7479996 & 197.0312484 & 152.0255024 & 151.8842240 \\
\hline 2 & 6.4516 & 0.645160000 & 0.645160000 & 0.645160000 & 0.645160000 \\
\hline 3 & 6.4516 & 150.1545384 & 149.6078266 & 163.0770932 & 163.1232003 \\
\hline 4 & 6.4516 & 98.61915760 & 98.22918330 & 92.5352988 & 92.75779895 \\
\hline 5 & & 0.64516 & 0.6 & 0.645160000 & 0.645160000 \\
\hline 6 & 16 & 3.590315400 & & 12.70836168 & 12.70787948 \\
\hline 7 & 6.4516 & 48.18248428 & 48.02706763 & 80.0062916 & 79.87214746 \\
\hline 8 & 6.4516 & 136.7610168 & 135.7825567 & 82.9030600 & 82.79629923 \\
\hline 9 & & 139.47 & 138 & 130.8 & 131.1797334 \\
\hline 10 & 4516 & 0.645160000 & 0.645160000 & 0.645160000 & 0.645160000 \\
\hline \begin{tabular}{c|} 
Truss \\
weight, $\mathrm{kN}$ \\
\end{tabular} & 1.8666727 & 22.51500912 & 22.51356469 & 20.80022802 & 20.80595725 \\
\hline \multicolumn{2}{|c|}{$\begin{array}{l}\text { Number of active } \\
\text { constraints }\end{array}$} & 4 & 5 & 4 & 6 \\
\hline \multicolumn{2}{|c|}{$\begin{array}{l}\text { Numbers of active } \\
\text { constraints }\end{array}$} & - & $\begin{array}{c}2,5,10,13, \\
31\end{array}$ & - & $\begin{array}{c}2,5,10,17, \\
31,32 \\
\end{array}$ \\
\hline \multicolumn{2}{|c|}{$\begin{array}{l}\text { Modulus of the } \\
\text { maximum violation in } \\
\text { the constraints }\end{array}$} & $0.27 \cdot 10^{-4}$ & $\begin{array}{c}\left|\delta \psi_{13}\right|=2.041 \\
\times 10^{-13}\end{array}$ & $0.17 \cdot 10^{-3}$ & $\begin{array}{c}\left|\delta \psi_{17}\right|=2.824 \\
\times 10^{-12}\end{array}$ \\
\hline
\end{tabular}

where $x_{j}, z_{j}$ are linear displacements of $j^{\text {th }}$ truss node, $j=\overline{1,4}$.

Comparison of the optimisation results for the 10-bar cantilever truss

Starting from the initial truss design with start weight $G^{0}=1.867 \mathrm{kN}$ optimal solution with optimum weight $G^{*}=22.514 \mathrm{kN}$ has been obtained for the truss subjected to the first load case. Additionally, starting from the initial truss design with start weight $G^{0}=1.867 \mathrm{kN}$ optimal solution with optimum weight $G^{*}=20.806 \mathrm{kN}$ has been obtained for the truss subjected to the first load case. Comparison of the optimisation results for three-bar truss under consideration obtained by authors of the paper [6] and in this article is presented by Table 3.5 .

For both loaded cases iterative searching process for the optimum point was stopped due to the following stop criterion: increment of the design variables within two consecutive iterations was less than 0.0001 , as well as there were no 
violated constraints.

Comparison of the optimisation results for the ten-bar cantilever truss obtained using the proposed improved method of objective function gradient projection onto the active constraints surface with simultaneous correction of the constraints violations with optimisation results presented by the literature $[3,6$, 14, 16] are shown in Table 3.6.

Table 3.6

Comparison of the optimisation results for the 10-bar cantilever truss

\begin{tabular}{|l|c|c|c|c|}
\hline \multirow{2}{*}{ Weight, $\mathrm{kN}$} & \multicolumn{2}{|c|}{ Load case 1 } & \multicolumn{2}{c|}{ Load case 2 } \\
\cline { 2 - 5 } & $\begin{array}{c}\text { Stresses } \\
\text { constraints only }\end{array}$ & All constraints & $\begin{array}{c}\text { Stresses } \\
\text { constraints only }\end{array}$ & All constraints \\
\hline This paper & 7.086663425 & 22.51356469 & 7.404064841 & 20.8059573 \\
The paper [6] & 7.086783276 & 22.51500912 & 7.408610546 & 20.8003614 \\
The paper [16] & 7.087005686 & 22.58284417 & 7.404251310 & 20.8039200 \\
The paper [14] & 7.086783276 & 22.58199901 & 7.404162346 & 20.8038755 \\
The paper [3] & 7.2149804 & 22.59685600 & - & 22.5065575 \\
\hline
\end{tabular}

3.3. Optimisation of a 24-bar translational tower. Parametric optimization problem for a translational tower (see Fig. 3.3) has been considered by the paper

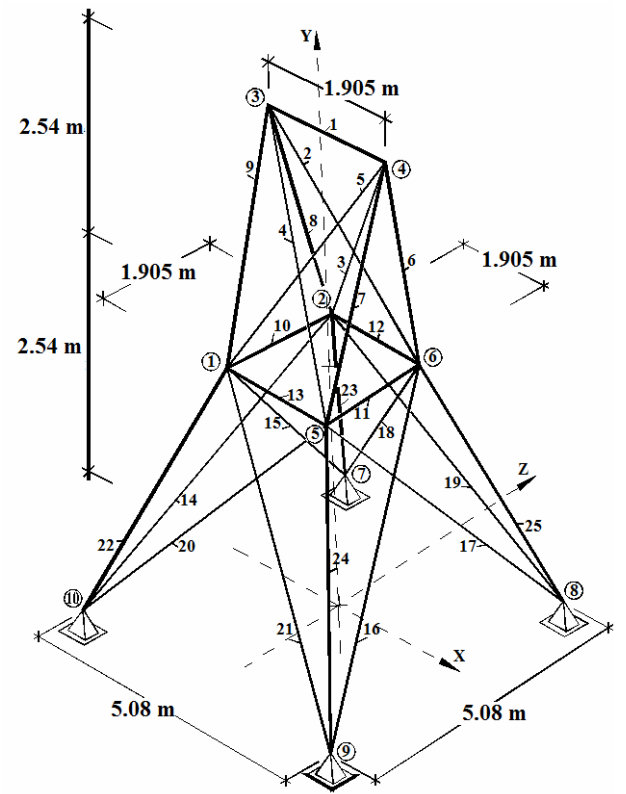

Fig. 3.3. Design model of the translational tower [6]. The translation tower is subjected to 2 load cases (see Table 3.7). Taking into account the symmetry of the structural form, the vector of the design variables has been reduced to 7 variable cross-section areas for 25 structural members of the tower under consideration (see Table 3.8). The parametric optimization problem is formulated as searching for optimum crosssectional areas $\vec{X}=\left(X_{i}\right)^{T}$, $i=\overline{1,7}$, of the tower structural members, whose provide the least weight of the tower subjected to stresses constraints, node displacements constraints, as well as constraints on the minimal cross-section areas.

Initial data for optimisation of the tower are as follows: unit weight of the tower material is $\rho g=0.1$ pound $/ \mathrm{inch}^{3}=2.768 \mathrm{t} / \mathrm{m}^{3}$; modulus of elasticity is $E=10^{7} \mathrm{pound} / \mathrm{inch}^{2}=703.074 \mathrm{t} / \mathrm{cm}^{2}$; non-dimensional factor used 
to calculate second moment area of inertia for each tower structural member is $\beta=1.0\left(I_{i}=\beta b_{i}^{2}\right)$; lower limit value for cross-sectional areas for all tower members is $A^{L}=0.01 \mathrm{inch}^{2}=0.0645 \mathrm{~cm}^{2}$; ultimate node displacements of the tower are $x^{a}=y^{a}=z^{a}=0.35 \mathrm{inch}=8.89 \mathrm{~mm}$; allowable stresses value for the all tower member is $\sigma^{a}= \pm 40 \cdot 10^{3}$ pound $/$ inch $^{2}= \pm 2.8122 \mathrm{t} / \mathrm{cm}^{2}$.

Start value $A_{0}=1.0 \mathrm{inch}^{2}=6.4516 \mathrm{~cm}^{2}$ was used as start approximation for variable cross-sections areas for all members of the tower under consideration. Dimensions of the optimisation problem were 7 design variables and 129 constraints.

Comparison of the optimisation results for the translational tower is presented by Table 3.8. At the continuum optimum point there were 5 active constraints: $3^{\text {rd }}$ node displacement constraint of the tower along axis $0 x$ for $1^{\text {st }}$ and $2^{\text {nd }}$ load cases, $3^{\text {rd }}$ node displacement constraint along axis $0 z$ for $1^{\text {st }}$ load case, $4^{\text {th }}$ node displacement constraint along axis $0 x$ for $2^{\text {nd }}$ load case, as well as $4^{\text {th }}$ node displacement constraint along axis $0 z$ for $1^{\text {st }}$ load case. Internal axial forces at the optimum design of the translational tower are shown by Table 3.9.

Table 3.7

Load cases for translational tower

\begin{tabular}{|c|c|c|c|c|}
\hline \multirow{2}{*}{$\begin{array}{c}\text { Load case } \\
\text { number }\end{array}$} & $\begin{array}{c}\text { Node number } \\
\text { (see Fig. 3.3) }\end{array}$ & \multicolumn{3}{|c|}{ Direction of the node load application } \\
\cline { 3 - 5 } & 1 & 0.2268 & $0 y$ & $0 z$ \\
\hline \multirow{4}{*}{1} & 2 & 0.2268 & - & - \\
\cline { 2 - 5 } & 3 & 0.4536 & -2.2680 & 4.5359 \\
\cline { 2 - 5 } & 4 & - & -2.2680 & 4.5359 \\
\hline \multirow{2}{*}{2} & 3 & - & -2.2680 & 9.0718 \\
\cline { 2 - 5 } & 4 & - & -2.2680 & -9.0718 \\
\hline
\end{tabular}

Table 3.8

Comparison of the optimisation results for the translational tower

\begin{tabular}{|c|c|c|c|}
\hline \multirow{2}{*}{$\begin{array}{c}\text { Design } \\
\text { variable }\end{array}$} & \multirow{2}{*}{$\begin{array}{c}\text { Tower structural } \\
\text { members (see Fig. 3.3) }\end{array}$} & \multicolumn{2}{|c|}{$\begin{array}{c}\text { Optimal cross-section areas for towe } \\
\text { members, } \mathrm{cm}^{2}\end{array}$} \\
\hline & & Paper [6] & This paper \\
\hline$A_{1}$ & 1 & 0.0645 & 0.0939 \\
\hline$A_{2}$ & $2,3,4,5$ & 13.2103 & 0.2444 \\
\hline$A_{3}$ & $6,7,8,9$ & 19.3322 & 23.8915 \\
\hline$A_{4}$ & $10,11,12,13$ & 0.0645 & 8.6632 \\
\hline$A_{5}$ & $14,15,16,17$ & 4.4213 & 5.0950 \\
\hline$A_{6}$ & $18,19,20,21$ & 10.4626 & 1.8024 \\
\hline$A_{7}$ & $22,23,24,25$ & 17.2335 & 25.2070 \\
\hline & Tower weight, $\mathrm{t}$ & 0.2472 & 0.2207 \\
\hline
\end{tabular}


Table 3.9

Internal axial forces at the optimum design of the translational tower, ton-force

\begin{tabular}{|c|c|c|c|c|c|c|c|c|}
\hline \multirow{2}{*}{$\begin{array}{l}\text { Bar } \\
\text { No. }\end{array}$} & \multicolumn{2}{|c|}{ Load case } & \multirow{2}{*}{$\begin{array}{l}\text { Bar } \\
\text { No. }\end{array}$} & \multicolumn{2}{|c|}{ Load case } & \multirow{2}{*}{$\begin{array}{l}\text { Bar } \\
\text { No. }\end{array}$} & \multicolumn{2}{|c|}{ Load case } \\
\hline & 1 & 2 & & 1 & 2 & & 1 & 2 \\
\hline 1 & -0.1433 & 0.00 & 10 & -0.0821 & -0.5387 & 18 & -0.4685 & 2.5114 \\
\hline 2 & -0.3292 & 0.00 & 11 & -0.1304 & 0.5387 & 19 & -0.5370 & -2.5114 \\
\hline 3 & 0.0654 & 0.00 & 12 & -3.9711 & 0.00 & 20 & 0.3682 & 2.5114 \\
\hline 4 & -0.2108 & 0.00 & 13 & 2.5968 & 0.00 & 21 & 0.2997 & -2.5114 \\
\hline 5 & 0.1839 & 0.00 & 14 & -1.4834 & -0.4803 & 22 & 5.8160 & -3.7169 \\
\hline 6 & -7.7237 & 4.8443 & 15 & 1.2554 & -0.4803 & 23 & -7.6930 & -3.7170 \\
\hline 7 & 5.0976 & 4.8443 & 16 & -1.5765 & 0.4803 & 24 & 5.0270 & 3.7169 \\
\hline 8 & -7.4008 & -4.8443 & 17 & 1.1623 & 0.4803 & 25 & -8.4820 & 3.7169 \\
\hline 9 & 5.4205 & -4.8443 & & & & & & \\
\hline
\end{tabular}

Iterative searching process for the optimum point was stopped due to the following stop criterion: increment of the design variables within two consecutive iterations was less than $1 \times 10^{-6}$, as well as there were no violated constraints (maximum value among constraint violations was $0.049 \times 10^{-10}$ ).

Conslusion. The method of the objective function gradient projection onto the active constraints surface with simultaneous correction of the constraints violations has been considered by the paper. Equivalent Householder transformations of the resolving equations of the method have been proposed. They increase numerical efficiency of the algorithm developed based on the method under consideration.

Additionally, proposed improvement for the gradient-based method also includes equivalent transformations (Givens rotations) of the resolving equations. They ensure acceleration of the iterative searching process in specified cases described by the paper due to decreasing the amount of calculations.

Lengths of the gradient vectors for objective function, as well as for constraints remain as they were in scope of the proposed equivalent transformations ensuring the reliability of the optimisation algorithm.

The comparison of the optimisation results presented by the paper confirms the validity of the optimum solutions obtained using proposed improvement of the gradient-based method. Start values of the design variables have no influence on the optimum solution of the non-linear problem confirming in such way accuracy and validity of the optimum solutions obtained using the algorithm developed based on the presented improved gradient-based method. The efficiency of the propoced improvement of the gradient-based method has been also confirmed taking into account the number of iterations and absolute value of the maximum violation in the constraints. The deviations availabled in some presented results can be explained, on the one hand, by using a numerical approach to the iterative searching with specified accuracy (as in the optimisation of the ten-bar cantilever truss), on the other hand, by possible existence of several local optimum points (as in the optimisation of the translation tower). 


\section{REFERENCES}

1. Bindel D., Demel J., Kahan W., Marques $O$. On computing Givens rotations reliably and efficiently. LAPACK Working Note 148. - University of Tennessee, UT-CS-00-449. - 2001.

2. Crowder N. P., Denbo R.S., MulveyJ.M. Reporting computational experiments in mathematical programming // Mathematical Programming. - Vol. 15, 1978. - p. 316-329.

3. Dobbs M. W., Nelson R. B. Application of optimality criteria to automated structural design // AIAA Journal. - Vol. 14(10), 1976. - p. 1436-1443.

4. Golub G. H., Van Loan, Charles F. Matrix Computations. - Johns Hopkins, 1996.

5. Guljaev V. I., Bazhenov V. A., Koshkin V. L. Optimisation methods in structural mechanic. Kyiv, 1988. - 192 p. (rus)

6. Haug E. J., Arora J. S. Applied optimal design: mechanical and structural systems. - John Wiley \& Sons, 1979. - $520 \mathrm{p}$.

7. Huebner K. H., Dewhirst D. L., Smith D. E., Byrom T. G. The finite element method for engineers $\left(4^{\text {th }}\right.$ ed. $)-$ John Wiley \& Sons, Inc. 2001. -744 p.

8. Kuci E., Henrotte F., Duysinx P., Geuzaine C. Design sensitivity analysis for shape optimization based on the Lie derivative // Computer methods in applied mechanics and engineering. - Vol. 317, 2017. - p. 702-722. https://doi.org/10.1016/i.cma.2016.12.036

9. Peleshko I., Yurchenko V. An optimum structural computer-aided design using update gradient method // Proceedings of the $8^{\text {th }}$ International Conference "Modern Building Materials, Structures and Techniques". - Faculty of Civil Engineering, Vilnius Gediminas Technical University, 2004. - p. $860-865$.

10. Permyakov V.O., Yurchenko V.V., Peleshko I. D. An optimum structural computer-aided design using hybrid genetic algorithm // Proceeding of the International Conference "Progress in Steel, Composite and Aluminium Structures". - Taylor \& Francis Group, London, 2006. p. 819-826.

11. Perelmuter A., Yurchenko $V$. Parametric optimization of steel shell towers of high-power wind turbines // Procedia Engineering. - No. 57, 2013. - p. 895 - 905. DOI: https://doi.org/10.1016/ j.proeng.2013.04.114.

12. Press W. H., Teukolsky S.A., Vetterling W. T., Flannery B. P. Givens method. Numerical recipes: the art of scientific computing. - New York: Cambridge University Press. -2007.

13. Reklaitis G. V., Ravindran A., Ragsdell K. M. Engineering optimization. Methods and applications. - Wiley, 2006. -688 p.

14. Rizzi $P$. The optimization of structures with complex constraints via a general optimality criteria method. Ph. D. thesis. - Stanford University, Palo Alto, CA, 1976.

15. Schmit L. A. (Jr.), et al. Structural synthesis. Vol. 1. Summer course notes. - Case institute of technology, 1965.

16. Schmit L. A. (Jr.), Miura H. A. New structural analysis. Synthesis capability. ACCESS $1 / /$ AIAA Journal. - Vol. 14(5), 1976. - p. 661-671.

17. Yurchenko V., Peleshko I., Beliaev N. Parametric optimization of steel truss with hollow structural members based on update gradient method // Proceedings of International Conference "Design, Fabrication and Economy of Metal Structures". - Springer Berlin Heidelberg, 2013. - p. 103-109. DOI: https://doi.org/10.1007/978-3-642-36691-8_16

18. Wilkinson J. H., Reinsch C. Handbook for Automatic Computation. Volume II: Linear Algebra. - Heidelberg New York Springer-Verlag Berlin, 1971. - 441 p. DOI: https://doi.org/10.1137/1014116 


\section{Пелешко І. Д., Юрченко В. В.}

\section{МОДИФІКАЦІЯ ГРАДІЕНТНОГО МЕТОДУ ДЛЯ РОЗВ'ЯЗКУ ЗАДАЧ ПАРАМЕТРИЧНОЇ ОПТИМІЗАЦІЇ СТЕРЖНЕВИХ КОНСТРУКЦІЙ}

У статті розглядаються задачі параметричної оптимізації стержневих конструкцій, які формулюються в термінах задачі нелінійного програмування. Об'єктом дослідження виступає метод, що грунтуються на обчисленні градієнтів функції мети та обмежень, а задачею дослідження - розробка математичного та алгоритмічного забезпечення для розв'язку задач параметричної оптимізації конструкцій при орієнтації на програмну реалізацію в системі автоматизованого проектування.

Для розв'язку задач параметричної оптимізації використовується метод проекції градієнта функції мети на поверхню активних обмежень з одночасною ліквідацією нев'язок в обмеженнях. У статті запропоновані еквівалентні перетворення Хаусхолдера для розв'язувальних рівнянь розглядуваного методу оптимізації, які підвищують обчислювальну ефективність алгоритму, розробленого на основі градієнтного методу. Окрім того запропоновані еквівалентні перетворення Гівенса для розв'язувальних рівнянь розглядуваного методу, які для визначених випадків, обумовлених у статті, пришвидшують ітераційний процес пошуку оптимального розв'язку внаслідок скорочення обсягу обчислень. Довжини векторів градієнтів функції мети та обмежень математичної моделі залишаються незмінними при запропонованих еквівалентних перетвореннях, що забезпечує надійність алгоритму оптимізації.

Порівняння результатів оптимізаціних розрахунків стержневих систем, представлене у статті, підтверджує достовірність оптимальних розв'язків, отриманих 3 використанням запропонованої модифікації градієнтного методу. Ефективність запропонованої модифікації градієнтного методу оптимізації, що розглядається, також підтверджується кількістю ітерацій та абсолютним значенням максимальної нев'язки в обмеженнях.

Ключові слова: параметрична оптимізація, задача нелінійного програмування, градієнтний метод, стержнева система, метод скінчених елементів

\section{Peleshko I. D., Yurchenko V. V.}

\section{AN IMPROVED GRADIENT-BASED METHOD TO SOLVE PARAMETRIC OPTIMISATION PROBLEMS OF THE BAR STRUCTURES}

The paper considers parametric optimisation problems for the bar structures formulated as nonlinear programming tasks. In the paper a gradient-based method is considered as investigated object. The main research question is the development of mathematical support and numerical algorithm to solve parametric optimisation problems of the building structures with orientation on software implementation in a computer-aided design system.

The method of the objective function gradient projection onto the active constraints surface with simultaneous correction of the constraints violations has been used to solve the parametric optimisation problem. Equivalent Householder transformations of the resolving equations of the method have been proposed by the paper. They increase numerical efficiency of the algorithm developed based on the method under consideration. Additionally, proposed improvement for the gradient-based method also consists of equivalent Givens transformations of the resolving equations. They ensure acceleration of the iterative searching process in the specified cases described by the paper due to decreasing the amount of calculations. Lengths of the gradient vectors for objective function, as well as for constraints remain as they were in scope of the proposed equivalent transformations ensuring the reliability of the optimisation algorithm.

The comparison of the optimisation results of truss structures presented by the paper confirms the validity of the optimum solutions obtained using proposed improvement of the gradient-based method. Start values of the design variables have no influence on the optimum solution of the nonlinear problem confirming in such way accuracy and validity of the optimum solutions obtained using the algorithm developed based on the presented improved gradient-based method. The efficiency of the propoced improvement of the gradient-based method has been also confirmed taking into account the number of iterations and absolute value of the maximum violation in the constraints.

Keywords: bar system, parametric optimisation, non-linear programming task, gradient-based method, finite-element method 
Пелешко И. Д., Юрченко В. В.

\section{УЛУЧШЕННЫЙ ГРАДИЕНТНЫЙ МЕТОД ДЛЯ РЕШЕНИЯ ЗАДАЧ ПАРАМЕТРИЧЕСКОЙ ОПТИМИЗАЦИИ СТЕРЖНЕВЫХ КОНСТРУКЦИЙ}

В статье рассматриваются задачи параметрической оптимизации стержневых конструкций, формулируемые в терминах задачи нелинейного программирования. Объектом исследования выступает метод, базирующийся на вычислении градиентов функции цели и ограничений, а задачей исследования служит разработка математического и алгоритмического обеспечения для решения задач параметрической оптимизации конструкций при ориентации на программную реализацию в системе автоматизированного проектирования.

Для решения задач параметрической оптимизации используется метод проекции градиента функции цели на поверхность активных ограничений с одновременной ликвидацией невязок в ограничениях. В статье предложены эквивалентные преобразования Хаусхолдера для разрешающих уравнений рассматриваемого метода оптимизации, повышающие численную эффективность алгоритма, разработанного на основе градиентного метода. Кроме того, предложены эквивалентные преобразования Гивенса для разрешающих уравнений рассматриваемого метода, обеспечивающие в определенных случаях, оговоренных в статье, ускорение итерационного процесса поиска оптимального решения вследствие уменьшения объема вычислений. Длины векторов градиентов функции цели и ограничений математической модели остаются неизменными при предложенных эквивалентных преобразованиях, что обеспечивает надежность оптимизационного алгоритма.

Сравнение результатов оптимизационных расчетов стержневых систем, представленных в статье, подверждает достоверность оптимальных решений, полученных с использование предложенного улучшения градиентного метода. Эффективность предложенного улучшения рассматриваемого метода оптимизации также подтверждается количеством итераций и абсолютнім значением максимальной невязки в ограничениях.

Ключевые слова: стержневая конструкция, параметрическая оптимизация, нелинейное программирование, градиентный метод, метод конечных элементов

УДК 519.853, 624.04

Пелешко І.Д., Юрченко В.В. Модифікація градіснтного методу для розв'язку задач параметричної оптимізації стержневих конструкцій // Опір матеріалів і теорія споруд: наук.-тех. збірн. - К.: КНУБА, 2020. - Вип. 104. - С. 265-288.

У статті розглядаються задачі параметричної оптимізаиії стержневих конструкиій, які формулюються в термінах задачі нелінійного програмування. Для розв'язку задач параметричної оптимізації використовується метод проекиії градієнта функиії мети на поверхню активних обмежень з одночасною ліквідацією нев'язок в обмеженнях. У статті запропоновані еквівалентні перетворення Хаусхолдера для розв'язувальних рівнянь розглядуваного методу оптимізації, які підвищують обчислювальну ефективність алгоритму, розробленого на основі градієнтного методу. Окрім того запропоновані еквівалентні перетворення Гівенса для розв'язувальних рівнянь розглядуваного методу, які для визначених випадків, обумовлених у статті, пришвидшують ітерачійний процес пошуку оптимального розв'язку внаслідок скорочення обсягу обчислень. Порівняння результатів оптимізаціних розрахунків стержневих систем, представлене у статті, підтверджує достовірність оптимальних розв'язків, отриманих з використанням запропонованої модифікаиії градієнтного методу.

Іл. 6. Табл. 9. Бібліог. 18 назв.

UDC 519.853, 624.04

Peleshko I. D., Yurchenko V.V. An improved gradient-based method to solve parametric optimisation problems of the bar structures // Strength of Materials and Theory of Structures: Scientific-and-technical collected articles - Kyiv: KNUBA, 2020. - Issue 104. - P. 265-288.

The paper considers parametric optimisation problems for the bar structures formulated as non-linear programming tasks. The method of the objective function gradient projection onto the active constraints surface with simultaneous correction of the constraints violations has been used 
to solve the parametric optimisation problem. Equivalent Householder transformations of the resolving equations of the method have been proposed by the paper. They increase numerical efficiency of the algorithm developed based on the method under consideration. Additionally, proposed improvement for the gradient-based method also consists of equivalent Givens transformations of the resolving equations. They ensure acceleration of the iterative searching process in the specified cases described by the paper due to decreasing the amount of calculations. The comparison of the optimisation results of truss structures presented by the paper confirms the validity of the optimum solutions obtained using proposed improvement of the gradient-based method.

Figs. 6. Tabs. 9. Refs. 18.

УДК 519.853, 624.04

Пелешко И.Д., Юрченко В.В. Улучшенный градиентный метод для решения задач параметрической оптимизации стержневых конструкций // Сопротивление материалов и теория сооружений: науч.- тех. сборн. - К.: КНУСА, 2020. - Вып. 104. - С. 265-288.

B статье рассматриваются задачи параметрической оптимизации стержневых конструкций, формулируемые в терминах задачи нелинейного программирования. Для решения таких задач используется метод проекции градиента функции цели на поверхность активных ограничений с одновременной ликвидацией невязок в ограничениях. Предложень эквивалентные преобразования Хаусхолдера для разрешающих уравнений рассматриваемого метода оптимизации, обеспечивающие численную эффективность алгоритма, разработанного на основе градиентного метода. Кроме того, предложень эквивалентные преобразования Гивенса для разрешающих уравнений рассматриваемого метода, обеспечивающие в определенных случаях, оговоренных в статье, ускорение итерационного процесса поиска оптимального решения вследствие уменьшения объема вычислений. Сравнение результатов оптимизационных расчетов стержневых систем, представленных в статье, подверждает достоверность оптимальных решений, полученных с использование предложенного улучшения градиентного метода.

Ил. 6. Табл. 9. Библиог. 18 назв.

Автор: кандидат технічних наук, доцент кафедри будівельного виробництва

Пелешко Іван Дмитрович

Адреса робоча: 79013 Украӥна, м. Львів, вул.. Ст. Бандери 12, Національний університет «Львівська політехніка»

Робочий тел.: +38 (032) 258-25-41

Мобільний тел..: +38(098) 41-57-517

E-mail: ipeleshko@polynet.lviv.ua

SCOPUS ID: 25637832500

ORCID ID: https://orcid.org/0000-0001-7028-9653

Автор: доктор технічних наук, професор кафедри металевих та дерев'яних конструкцій Юрченко Віталіна Віталї̈на

Адреса робоча: 03680 Украӥна, м. Київ, Повітрофлотський пр. 31, Київський національний університет будівництва і архітектури

Робочий тел.: +38(044)249-71-91

Мобільний тел..: +38(063)89-26-491

E-mail: vitalina@scadsoft.com

SCOPUS ID: 25637856200

ORCID ID: https://orcid.org/0000-0003-4513-809X 